\title{
Studi Satuan Biaya Pendidikan Sekolah Dasar di Jakarta
}

\author{
Ngadirin \\ ngadirin@yahoo.com
}

\begin{abstract}
ABSTRAK: Penelitian ini bertujuan untuk menganalisis kebijakan pemerintah dalam bidang pembiayaan pendidikan dasar yang merupakan wajib belajar bagi setiap warga negara, dengan fokus pada pembiayaan sekolah dasar. Analisis yang dilakukan termasuk menghitung biaya satuan pendidikan untuk sekolah dasar. Hasil analisis menunjukkan bahwa terdapat beberapa ketidakkonsistenan peraturan yang berkaitan dengan pembiayaan pendidikan, termasuk kebijakan dan pelaksanaan wajib belajar pendidikan dasar. Satuan biaya pendidikan untuk sekolah dasar adalah sebesar Rp1.767.000,00 per siswa per tahun yang jauh lebih besar dari alokasi satuan biaya yang diterapkan saat ini. Hasil penelitian ini sangat penting untuk diperhatikan oleh berbagai pihak sebagai masukan bagi penyusunan kebijakan publik, terutama melalui peninjauan kembali beberapa peraturan untuk menjaga konsistensi antarkebijakan.
\end{abstract}

Kata kunci: konsisten kebijakan, pembiayaan pendidikan, satuan biaya pendidikan, sekolah dasar, kebijakan pendidikan, wajib belajar.

ABSTRACT: The aim of this research is to examine the government policy in financing basic education in the frame of compulsory education which focuses on the educational policy for primary school. This includes an evaluation of all regulations related to financing education and calculation on finding the student unit cost at primary level through a survey to provide a reference for the government in allocating budget for education. The result of research shows that there are some inconsistencies in the regulations related to financing education. This includes the implementation policy on financing basic education in the frame of compulsory basic education. It is found that the education unit cost for primary school level is IDR $1,767,000$ per student per year. It is much higher than the current budget allocated. These findings seem to be important for all parties as a feedback and reflection for the government policy including reviewing some regulations to avoid inconsistency.

Keywords: policy's consistency, education unit cost, financing education, primary school, educational policy, compulsary education.

\section{Pendahuluan}

Pendidikan merupakan salah satu faktor penting dalam pertumbuhan suatu bangsa, karena pendidikan terkait langsung dengan pembangunan sumber daya manusia. Pendidikan yang bermutu akan menghasilkan sumber daya yang berkualitas dan kualitas sumber daya manusia menentukan perkembangan bangsa. Dengan demikian dapat dimengerti bahwa pendidikan merupakan investasi bagi masa depan bangsa dan berpengaruh kuat terhadap pertumbuhan ekonomi negara. Frederick Harbison dan Charles A. Myers (1965) menyatakan bahwa Investment in education certainly contributes to economic growth, but it is also obvious that economic growth makes it possible for nations to invest in educational development. Hal senada juga disampaikan oleh John, Roe L \& Morphet, Edgar L. (1969) bahwa warga negara yang berpendidikan lebih berpotensi untuk membangun bangsa. Selain itu investasi di bidang pendidikan dapat membangun sumber daya manusia yang berkualitas yang pada akhirnya dapat meningkatkan ekonomi bangsa dan demokrasi (Frederick Harbison dan Charles A. Myers, 1965).

Dalam usianya yang lebih dari setengah abad, Indonesia telah menempatkan pendidikan merupakan salah satu tujuan negara sebagaimana tertuang dalam Pembukaan UUD Tahun 1945 dalam rangka mencerdaskan kehidupan bangsa. Dalam peraturan perundangan juga disebutkan pentingnya penyelenggaraan pendidikan yang bermutu. Namun demikian, terdapat pertanyaan mendasar tentang apakah yang dimaksud dengan pendidikan yang bermutu sebagaimana disebut dalam Sistem Pendidikan Nasional. Apakah penyelenggaraan pendidikan bermutu adalah pendidikan yang bertaraf internasional, sekolah dengan kategori mandiri, atau sekolah yang sudah 
atau hampir memenuhi standar nasional pendidikan (SNP)? Pertanyaan berikutnya, apakah sekolah dengan kategori mandiri dapat menjamin pencapaian tujuan pendidikan yaitu untuk mengembangkan manusia Indonesia yang beriman dan bertakwa kepada Tuhan Yang Maha Esa, berakhlak mulia, sehat, berilmu, cakap, kreatif, mandiri, dan menjadi warga negara yang demokratis serta bertanggung jawab? Apa pun jawabannya, kenyataannya mutu pendidikan di Indonesia masih sangat rendah sebagaimana disampaikan the World Bank (2005).

Berkaitan dengan anggaran pendidikan, Perubahan ke empat UUD Tahun 1945 mengamanatkan prioritas anggaran pendidikan minimum $20 \%$ dari APBN dan APBD. Pertanyaannya adalah, apakah dengan alokasi $20 \%$ sudah dapat menjamin untuk dapat mendukung penyelenggaraan pendidikan yang bermutu? Sebenarnya berapa anggaran pendidikan yang diperlukan untuk menyelenggarakan pendidikan bermutu di Indonesia? Di tingkat implementasi, ada kebijakan pemerintah untuk menyelenggarakan pendidikan dasar "gratis" dalam rangka pendidikan yang bermutu. Apakah kebijakan praktis ini sudah sesuai dengan amanat UU Nomor 20 Tahun 2003?

Berdasarkan uraian di atas, rumusan permasalahan yang diangkat dalam penelitian ini yaitu: 1) Bagaimanakah konsistensi kebijakan Pemerintah dalam hal pembiayaan pendidikan yang diwujudkan dalam peraturan perundangan mulai dari peraturan yang paling tinggi sampai ke peraturan di tingkat menteri serta implementasinya? 2) Apakah yang dimaksud dengan penyelenggaraan pendidikan bermutu berdasarkan peraturan perundangan di Indonesia dan persepsi yang berkembang di lapangan? 3) Apakah alokasi anggaran pendidikan $20 \%$ dari APBN dan APBD realistis dan dapat menjamin terselenggaranya pendidikan yang bermutu di Indonesia sebagaimana diamanatkan oleh undang-undang? 4) Berapa sesungguhnya anggaran pendidikan yang dibutuhkan untuk mendukung penyelenggaraan pendidikan dasar yang bermutu khususnya pada jenjang sekolah dasar yang didasarkan pada analisis kebutuhan?

Penelitian ini bertujuan untuk melakukan analisis terhadap kebijakan yang sudah dikeluarkan pemerintah (analysis of policy) bukan untuk mendukung suatu kebijakan (analysis for policy). Penelitian ini difokuskan pada analisis terhadap konsistensi kebijakan pembiayaan pendidikan dasar, penggalian persepsi tentang maksud dari penyelenggaraan pendidikan yang bermutu, penghitungan satuan biaya pendidikan jenjang sekolah dasar, serta perkiraan anggaran nasional yang diperlukan untuk mendukung terpenuhi penyelenggaraan pendidikan yang bermutu.

\section{Kajian Literatur Pendidikan dan Pembangunan Bangsa}

Pendidikan adalah suatu tindakan atau proses untuk menyampaikan atau memperoleh pengetahuan umum, mengembangkan kemampuan nalar dan mengambil keputusan, dan secara umum mempersiapkan diri sendiri atau orang lain untuk hidup secara dewasa (Shenith Jackson, 2008). Pendidikan harus ditujukan untuk mengembangkan semua potensi anak untuk menghormati orangtua, budaya, bahasa dan nilai-nilai yang terkandung di dalamnya (Douglas Ray, et.al., 1994). Pendidikan harus bertujuan untuk mewujudkan perdamaian dan membangun demokrasi baik nasional maupun internasional karena tanpa perdamaian tidak akan ada hak asasi manusia (Federeco Mayor, 2001). Menempatkan pendidikan sebagai prioritas pembangunan telah terbukti menjadi negara yang maju (Suyanto \& Djihad Hisyam, 2000). Less Bell dan Howard (2006) pendidikan sebagai isu pokok pembangunan bangsa di Inggris dengan pernyataan:

Learning is the key to prosperity - for each of us as individuals as well as for the nation as a whole. Investment in human capital will be the foundation of success in the knowledge-based global economy. We need a well-educated, wellequipped labour force. Learning enables people to play a full part in their community. It strengthens the family, neighbourhood and consequently the nation.

Pendidikan merupakan isu ampuh dalam kampanye untuk meraih massa, walaupun isu tersebut lebih sering hilang setelah kursi diraih (Djaali, 2006). Dalam penyusunan anggaran pendidikan pun terjadi beda pandangan antara legislatif (baca politikus) dan birokrasi, sesuai dengan fungsi masingmasing (Mark Bray, 1996). Presiden Amerika George Walker Bush melakukan reformasi pendidikan di Amerika dengan tema America 2000: An Educational Strategy (Suyanto \& Djihad Hisyam, 2000). Pendidikan merupakan rentetan dari kebijakan, alokasi anggaran, sumber daya, proses belajar- 
mengajar, keluaran pendidikan yang berpengaruh langsung pada kondisi sosial, politik, dan ekonomi suatu negara (Martin Carnoy dan Henry M. Levin, 1976).

Pendidikan merupakan investasi jangka panjang yang berpengaruh pada pertumbuhan ekonomi negara, sebagaimana dikemukakan oleh John dan Morphet (1969) bahwa, . . all the economists who have seriously researched this matter have concluded that investment in education has a vital effect upon economic growth. Negara yang memiliki sumber daya manusia berkualitas sebagai hasil dari pendidikan akan mampu menemukan dan memanfaatkan sumber daya alam, mengembangkan teknologi, menghasilkan komoditi bermutu, menggerakkan model, dan mampu mengelola perdagangan (Frederick Harbison, Charles A. Myers, 1965). Sehingga pendidikan harus direncanakan dengan baik dengan diukung oleh anggaran yang memadai (Frank W. Banghart dan Albert Trull, JR, 1973), (John \& Morphet, 1969), karena dapat memberikan nilai pengembalian (return) yang optimal (Peter Capezio, 2000). Namun perlu disadari bahwa pendidikan dipengaruhi oleh perkembangan politik (Martin Carnoy dan Henry M. Levin, 1976).

\section{Penyelenggaraan Pendidikan yang Bermutu}

Pendidikan merupakan suatu upaya terencana untuk membentuk manusia seperti yang diinginkan yang berkaitan dengan pengetahuan, informasi, keterampilan, peserta didik, dan pendidik. Pendidikan juga tidak terpisahkan dari masukan, proses, keluaran, dan outcome. Mutu pendidikan berkaitan dengan keluaran dan proses (Thomas J. Barry, 1996). Keluaran pendidikan termasuk kemampuan dasar peserta didik dalam berbicara, belajar bagaimana berpikir, kemampuan dalam pemecahan masalah, pengetahuan baik dalam bidang ilmu eksakta maupun sosial, sikap peserta didik, penyesuaian diri dengan lingkungan, fisik dan mental, serta kewarganegaraan (John, Roe L \& Morphet, Edgar L. 1969). Mutu pendidikan berkenaan dengan pemenuhan suatu produk pada kriteria, standar atau rujukan yang ditentukan (Komisi Nasional Pendidikan, 2001).

Penyelenggaraan pendidikan yang bermutu, menurut Prof. Soedijarto, adalah pendidikan seperti yang disediakan Belanda untuk orang Indonesia golongan elit pada masa penjajahan (HollandschInlandsche School (HIS) atau Sekolah Dasar Eropa
(Europeesche Lagere School - ELS), MULO (MeerUitgebreid Lager Onderwijs) dan AMS (Algemeene Middelbare School) untuk tingkat SMP dan HBS (Higere Burger School) untuk tingkat SMP-SMA. Negara berkembang yang hanya mengutamakan pada perluasan kesempatan memperoleh pendidikan (education for all) tetapi mengabaikan mutu, tidak akan berpengaruh pada kemajuan bangsa tetapi justru akan menimbulkan masalah kepada bangsa itu (Soedijarto, 2008).

Walaupun belum ada definisi tentang mutu pendidikan yang disepakati dan berlaku secara umum, tetapi rendahnya mutu pendidikan menjadi salah satu masalah yang menjadi tantangan. Penyelenggaraan pendidikan yang bermutu berkaitan dengan input, proses dan keluaran. Pendidikan yang bermutu akan menghasilkan keluaran dalam bentuk sumber daya manusia yang berpotensi dengan kemampuan dasar dalam berbicara, berpikir, memecahkan masalah, memiliki pengetahuan yang memadai untuk menyesuaikan diri dengan lingkungan, serta memiliki sikap dan mental sebagai warga negara.

\section{Kebijakan Pembiayaan Pendidikan di Indonesia}

Sistem penganggaran pendidikan merupakan salah satu isu dalam pendidikan di Indonesia, baik dari sisi prosedur penghitungan besar anggaran yang diperlukan secara menyeluruh maupun mekanisme penyalurannya. Besarnya anggaran pendidikan dasar yang menjadi kewajiban pemerintah belum ada kejelasan karena belum disepakatinya satuan biaya pendidikan per anak per Tahun, walaupun sudah ada rekomendasi besarnya satuan pendidikan per anak dari beberapa penelitian (Abbas Ghozali, dkk., 2004; Dedi Supriadi, 2003; McMahon, dkk., 2001; UNDP bersama BPS dan Bappenas, 2004). Salah satu alasan yang sering dipakai pemerintah untuk tidak memenuhi satuan biaya pendidikan adalah keterbatasan dana (Soedijarto, 2008).

Pemerintah Indonesia pernah memperhatikan pendidikan secara serius pada Tahun 50-an, yang dibuktikan dengan pembangunan delapan perguruan tinggi dalam kurun waktu 10 Tahun. Sayangnya hal itu tidak berlangsung secara terus-menerus. Perkembangan pendidikan di Indonesia yang saat ini sudah berusia lebih dari setengah abad ternyata tidak menunjukkan sesuatu yang menggembirakan sebagaimana diungkap dalam laporan pembangunan 
manusia Indonesia yang disusun oleh UNDP, Bappenas, dan BPS (2004) yang merekomendasikan:

Indonesia needs to invest more in human development - not just to fulfil its people basic rights but also to lay the foundation for economic growth and to ensure the long-term survival of its democracy. This investment is substantial but clearly affordable. It has to be based, however, on a widespread national consensus that could be fostered through a National Summit for Human Development.

\section{Metodologi Penelitian}

Model penelitian yang digunakan dalam penelitian ini adalah model retrospektif dengan menggabungkan antara pendapat Ann Majchrzak (1984), Wyne Pearson (2001), Edi Suharto (2005), dan Riant Nugroho (2007). Tahap penelitian ini tidak mencakup semua siklus, tetapi mengambil model analisis kebijakan yang mengarahkan kajiannya terhadap akibat dari penerapan suatu kebijakan. Model ini disebut juga model analisis kebijakan evaluatif karena banyak menggunakan pendekatan dengan melakukan evaluasi terhadap dampak dari suatu kebijakan yang sedang atau telah diimplementasikan (Edi Suharto, 2005). Permasalahan sosial yang diangkat dalam penelitian ini adalah belum dipenuhinya hak setiap warga negara Indonesia untuk mendapatkan pendidikan yang bermutu sedangkan hal tersebut merupakan amanat dari UUD Tahun 1945 yang dipertegas dalam Sistem Pendidikan Nasional. Permasalahan penelitian diarahkan pada kebijakan Pemerintah dalam mengalokasikan anggaran pendidikan dengan fokus pada analisis pembiayaan pendidikan untuk memperoleh satuan biaya pendidikan yang dapat mendukung penyelenggaraan pendidikan yang bermutu.

Metode yang diterapkan dalam penelitian ini sesuai dengan tujuan penelitian mencakup analisis peraturan perundangan, wawancara dan survei yang dilakukan pada Tahun 2010. Analisis dilakukan terhadap peraturan perundangan yang terkait dengan pembiayaan pendidikan. Wawancara dengan beberapa narasumber dimaksudkan untuk menggali persepsi tentang penyelenggaraan pendidikan yang bermutu serta hal-hal lain yang berkaitan dengan anggaran pendidikan. Survei tentang kebutuhan operasional sekolah dilakukan dimaksudkan untuk menghitung satuan biaya pendidikan pada jenjang sekolah dasar. Satuan biaya pendidikan yang diperoleh dipakai sebagai dasar dalam memperkirakan kebutuhan anggaran secara nasional. Jumlah seluruh responden dalam penelitian ini adalah 195 orang yang terdiri atas 7 (tujuh) orang pejabat di lingkungan Kementerian Pendidikan Nasional, 8 (delapan) orang akademisi perguruan tinggi, 3 (tiga) orang widyaiswara pendidikan, 7 (tujuh) orang kepala sekolah, 87 orang guru sekolah dasar, dan 83 siswa sekolah dasar.

Sasaran survei untuk menghitung satuan biaya pendidikan jenjang sekolah dasar dilakukan di 8 (delapan) sekolah dasar negeri percontohan berdasarkan Keputusan Kepala Dinas Pendidikan Dasar Prov. DKI Jakarta Nomor 35/2006 tanggal 20 Februari 2006. Ke delapan sekolah tersebut adalah SDN Menteng 01, SDN Kompleks UNJ, SDN Kebon Jeruk 11, SDN Rawajati 08, SDN Sunter Agung 12, SDN Pesanggarahan 10, dan SDN Ujung Menteng 04 (tetapi SD terakhir tidak bersedia menjadi responden penelitian ini).

\section{Hasil Penelitian dan Pembahasan Konsistensi Peraturan Perundangan tentang Kebijakan Pembiayaan Pendidikan di Indonesia}

Tata Urutan Perundangan Yang Berkaitan Dengan Pembiayaan Pendidikan

Menurut Ketetapan MPR Nomor III/MPR/2000, tata urutan peraturan perundangan di Indonesia dimulai dari dari yang tertinggi yaitu UUD Tahun 1945, Ketetapan MPR, Undang-undang, Peraturan Pemerintah Pengganti Undang-undang, Peraturan Pemerintah, Keputusan Presiden, dan Peraturan Daerah. Pada tataran implementasi di tingkat kementerian terdapat Peraturan Menteri, Keputusan Direktur Jenderal, dan diterjemahkan ke dalam pedoman atau petunjuk teknis pelaksanaan. Tata urutan perundangan yang berkaitan dengan kebijakan pembiayaan pendidikan dari yang tertinggi adalah UUD Tahun 1945, UU Nomor 20 Tahun 2003 Tentang Sistem Pendidikan Nasional, UU Nomor 32 Tahun 2004 tentang Pemerintahan Daerah, UU Nomor 33 Tahun 2004 Tentang Perimbangan Keuangan Antara Pemerintah Pusat dan Daerah, UU Nomor 14 Tahun 2005 Tentang Guru dan Dosen, UU Tentang APBN yang dikeluarkan setiap Tahun, Peraturan Pemerintah (PP) Nomor 19 Tahun 2005 Tentang Standar Nasional 
Pendidikan, PP Nomor 47 Tahun 2008 Tentang Wajib Belajar, PP Nomor 48 Tahun 2008 Tentang Pendanaan Pendidikan, PP Nomor 17 Tahun 2010 Tentang Pengelolaan dan Penyelenggaraan Pendidikan, dan PP Nomor 66 Tahun 2010 Tentang Perubahan PP Nomor 17 Tahun 2010.

Peraturan di tingkat kementerian yang berkaitan dengan kebijakan pembiayaan pendidikan antara lain Peraturan Mendiknas Nomor 19 Tahun 2009 Tentang Standar Pengelolaan Pendidikan, Peraturan Mendiknas Nomor 24 Tahun 2007 Tentang Standar Sarana dan Prasarana Pendidikan, Peraturan Mendiknas Nomor 2 Tahun 2008 Tentang Buku, Peraturan Mendiknas Nomor 63 Tahun 2009 tentang Sistem Penjaminan Mutu Pendidikan, Peraturan Mendiknas Nomor 69 Tahun 2009 Tentang Standar Biaya Operasi Nonpersonalia, Peraturan Mendiknas Nomor 78 Tahun 2009 Tentang Penyelenggaraan Sekolah Bertaraf Internasional, Peraturan Mendiknas Nomor 15 Tahun 2010 Tentang Standar Pelayanan Minimal Pendidikan di Kabupaten/Kota. Peraturan pada tingkat Direktur Jenderal yang terkait dengan pembiayaan pendidikan dasar adalah Panduan Bantuan Operasional Sekolah Untuk Pendidikan Gratis Dalam Rangka Wajib Belajar 9 Tahun Yang Bermutu yang dikeluarkan sejak Tahun 2005.

\section{Konsistensi UU Sisdiknas terhadap UUD Tahun 1945}

Dalam UU Nomor 20 Tahun 2003 Tentang Sistem Pendidikan Nasional terdapat pasal-pasal yang membahas tentang anggaran pendidikan. Undangundang Sisdiknas merupakan jabaran secara rinci dari pasal-pasal UUD Tahun 1945 yang berkaitan dengan pendidikan, sehingga berdasarkan tata urutan perundangan, UU Nomor 20 Tahun 2003 tidak boleh bertentangan dengan UUD Tahun 1945.

Dari hasil analisis diperoleh beberapa informasi tentang keterkaitan UUD Tahun 1945 dan UU Sisdiknas. Dalam rangka mencerdaskan kehidupan bangsa sebagaimana disebutkan dalam UUD Tahun 1945, dilakukan melalui pendidikan yang bertujuan untuk mengembangkan seluruh potensi peserta didik. Hak dan kewajiban setiap warga negara untuk mendapatkan pendidikan yang bermutu tanpa diskriminasi dan tanpa memungut biaya terdapat dalam UUD Tahun 1945 dan UU Sisdiknas.

Namun demikian, penjabaran pasal dari UUD Tahun 1945 ke dalam pasal-pasal UU Sisdiknas tidak semuanya sejalan. Ketidaksinkronan (inkonsistensi) antara UU Sisdiknas dan UUD Tahun 1945 terletak pada perbedaan cakupan substansi terkait dengan frase "selain gaji pendidik dan biaya pendidikan kedinasan". Belakangan Mahkamah Konstitusi Republik Indonesia melalui putusan nomor 24/PUUV/2007 memutuskan bahwa Pasal 49 Ayat (1) Undang-undang Nomor 20 Tahun 2003 tentang Sistem Pendidikan Nasional sepanjang mengenai frasa "gaji pendidik dan" bertentangan dengan Amandemen Undang-Undang Dasar Negara Republik Indonesia Tahun 1945 dan tidak mempunyai kekuatan hukum yang mengikat.

\section{Konsistensi Pasal-Pasal dalam UU Sisdiknas}

Jika pasal-pasal dalam UU Sisdiknas yang mengatur pembiayaan pendidikan disandingkan, maka akan terlihat adanya ketidaksinkronan isi dari antarpasal. Ketidaksinkronan tersebut terkait dengan kewajiban masyarakat dalam mendukung penyelenggaraan pendidikan, yaitu antara kewajiban masyarakat untuk memberikan dukungan sumber daya (Pasal 9 UU Sisdiknas) di sisi lain Pemerintah wajib membiayai pendidikan dasar tanpa memungut biaya (Pasal 11 dan Pasal 34 UU Sisdiknas dan Pasal 31 Ayat (2) UUD Tahun 1945).

\section{Konsistensi Antar Peraturan Pemerintah}

Beberapa Peraturan Pemerintah (PP) yang berkaitan langsung dengan kebijakan pembiayaan pendidikan di Indonesia, yaitu PP Nomor 19 Tahun 2005 tentang Standar Nasional Pendidikan (SNP), PP Nomor 47 Tahun 2008 tentang Wajib Belajar dan PP Nomor 48 Tahun 2008 tentang Pendanaan Pendidikan. Pembahasan juga dihubungkan dengan peraturan yang lebih tinggi yaitu UU Sisdiknas dan UUD Tahun 1945.

Berdasarkan hasil analisis terhadap beberapa PP di atas diperoleh informasi bahwa pasal-pasal dalam ketiga PP saling menguatkan dan saling melengkapi. Namun terdapat beberapa permasalahan yang terkait dengan penggunaan istilah dan cakupan substansi antara ketiga PP pada bagian yang membahas pembiayaan pendidikan, antara lain perbedaan substansi, ketidakkonsistenan peristilahan, ketidakjelasan cakupan, ketidakkonsistenan dalam pengelompokan komponen biaya, serta diperbolehkannya pungutan biaya berdasarkan PP Nomor 48/2008 tetapi dilarang oleh UUD Tahun 1945, UU Sisdiknas, dan PP Nomor 
47/2008. Ketidaksesuaian ini dapat berakibat pada kerancuan dan kekacauan pada peraturan di bawahnya serta implementasi dari peraturanperaturan tersebut.

\section{Konsistensi Kebijakan Pembiayaan Pendidikan di Tingkat Implementasi Kebijakan Pendidikan Gratis Pendidikan Dasar Melalui Bantuan Operasional Sekolah (BOS)}

Kebijakan pendidikan gratis telah dikeluarkan Pemerintah Pusat sejak Tahun 2005 melalui program yang disebut dengan pemberian bantuan operasi sekolah (BOS) untuk SD/MI dan SMP/MTs yang dibebankan pada APBN. Secara sepintas kebijakan tersebut seperti sebuah cahaya bagi penyelenggaraan pendidikan di Indonesia. Namun pada kenyataannya kebijakan tersebut bertentangan dengan peraturan yang dikeluarkan oleh pemerintah sendiri. Sebagai contoh, alokasi satuan biaya per anak untuk tingkat SD Tahun 2005 dan 2006 sebesar Rp235.000,00 dan menjadi Rp254.000,00 pada Tahun 2007 dan 2008, dan akhirnya pada Tahun 2009 dan 2010 ditingkatkan lagi menjadi Rp400.000,00 per Tahun per anak untuk wilayah kota dan Rp397.000,00 untuk wilayah kabupaten.

Namun demikian, kebijakan pemberian BOS untuk pendidikan gratis dalam rangka wajib belajar pendidikan dasar yang bermutu bertentangan dengan dengan Pasal 31 Ayat (2) UUD Tahun 1945 yang menyebutkan bahwa "Setiap warga negara wajib mengikuti pendidikan dasar dan pemerintah wajib membiayainya," dan Pasal 46 Ayat (2) UU Nomor 20 Tahun 2003 bahwa "Pemerintah dan pemerintah daerah bertanggung jawab menyediakan anggaran pendidikan", serta Pasal 34 Ayat (2) UU Nomor 20 Tahun 2003 yang mengharuskan pemerintah untuk menjamin terselenggaranya wajib belajar pendidikan dasar tanpa memungut biaya, maka pemerintah memang harus membiayai pendidikan. Artinya, program BOS yang seolah-olah merupakan wujud perhatian pemerintah pada pendidikan, justru hal itu sebaliknya menunjukkan bahwa pemerintah mengingkari tanggungjawabnya untuk membiayai pendidikan karena pemerintah seharusnya bukan memberikan bantuan kepada satuan pendidikan dasar tetapi wajib membiayai pendidikan dasar.

\section{Konsistensi Implementasi Kebijakan Pembiayaan Pendidikan untuk Sekolah Dasar melalui BOS}

Alokasi BOS Sekolah Dasar (yang seharusnya bukan bantuan tetapi biaya) secara bertahap mengalami kenaikan dari Rp235.000,00 pada Tahun 2005 menjadi Rp400.000,00 untuk wilayah kota dan Rp397.000,00 untuk wilayah kabupaten Tahun 2010. Namun demikian angka tersebut masih tetap di bawah standar biaya operasi nonpersonalia yang ditetapkan Pemerintah. Berdasarkan Peraturan Mendiknas Nomor 69 Tahun 2009 ditetapkan bahwa standar biaya operasi nonpersonalia Tahun 2009 untuk jenjang SD/MI adalah sebesar Rp580.000,00 per anak per Tahun. Kondisi ini sangat janggal, karena pemerintah mengeluarkan kebijakan pendidikan gratis alias tanpa memungut biaya, tetapi alokasi anggaran yang disediakan berada di bawah standar biaya yang dikeluarkan pemerintah sendiri.

\section{Kebijakan BOS dan Manajemen Berbasis Sekolah}

Dalam Undang-Undang Nomor 20 Tahun 2003 disebutkan bahwa pengelolaan satuan pendidikan termasuk pendidikan dasar dilaksanakan dengan prinsip manajemen berbasis sekolah (MBS). MBS merupakan bentuk otonomi manajemen pendidikan yang memberikan kewenangan lebih luas kepada sekolah untuk mengurus dirinya sendiri yang mencakup aspek perencanaan, pelaksanaan, monitoring dan evaluasi program sekolah. Dengan prinsip MBS, setiap sekolah seharusnya memperoleh kewenangan untuk merencanakan program sekolah yang sesuai dengan situasi dan kondisi sekolah dan di dalamnya termasuk anggaran yang dibutuhkan. Namun dari sisi anggaran pendidikan pada jenjang sekolah dasar, prinsip ini sepertinya hanya retorika karena perencanaan yang dilakukan sekolah hanya terbatas pada dana yang disediakan oleh pemerintah melalui BOS dengan alokasi yang masih jauh dari kebutuhan.

\section{Pendapat Lapangan tentang Pembiayaan SD melalui BOS}

Dari hasil wawancara dan kuesioner yang disebarkan kepada para pengambil kebijakan, praktisi pendidikan, kepala sekolah, dan guru diperoleh gambaran bahwa program Bantuan Operasional Sekolah (BOS) walaupun angkanya masih jauh dari kebutuhan yang 
sebenarnya, secara umum para responden mengakui program ini merupakan bentuk peningkatan perhatian pemerintah untuk membiayai pendidikan. Namun di kalangan sekolah, kebijakan BOS ternyata tidak selalu disambut dengan baik, bahkan sebagian berpendapat bahwa kebijakan ini telah membuat sekolah menjadi tidak leluasa akibat keterbatasan dana (karena besaran BOS kecil) tetapi tidak boleh memungut dari orangtua (harus gratis).

\section{Konsistensi Kebijakan Khusus pada Penyelenggaraan Sekolah Bertaraf Internasional}

Penyelenggaraan pendidikan bertaraf internasional di Indonsia diatur dalam UU Nomor 20/2003 khususnya Pasal 51 Ayat (4), PP Nomor 17/2010 tentang Pengelolaan dan Penyelenggaraan Pendidikan, PP Nomor 66/2010 tentang Perubahan Atas PP Nomor 17/2010, dan Peraturan Mendiknas Nomor 78/2008 tentang Penyelenggaraan Sekolah Bertaraf Internasional (SBI) Pada Jenjang Pendidikan Dasar dan Menengah.

Dalam kebijakan SBI yang dimaksudkan agar dimiliki pendidikan yang bermutu secara internasional, terdapat pembedaan status sekolah dari sekolah standar, sekolah standar nasional, dan sekolah bertaraf internasional. Selain itu, pada tataran implementasi, SBI hanya diperuntukkan bagi anakanak dari kalangan tertentu dengan adanya persyaratan tes potensi akademik dan kesediaan orangtua/wali untuk membayar pungutan untuk masuk ke SD bertaraf Internasional. Kondisi ini ditambah dengan perlakuan yang berbeda dari pemerintah terhadap sekolah yang dirintis untuk menjadi SBI dengan mempraktikkan "memupuk tanaman subur" yaitu dengan memberikan bantuan yang cukup besar kepada sekolah yang ditetapkan sebagai rintisan sekolah bertaraf internasional. Kebijakan ini bertentangan Pasal 31 Ayat (1) dengan UUD Tahun 1945 yang dipertegas dengan Pasal 5 Ayat (1) dan Pasal 11 Ayat (1) UU Sisdiknas yaitu bahwa setiap warga negara berhak mengikuti pendidikan dasar yang bermutu tanpa diskriminasi dan tanpa memungut biaya, serta pemerintah wajib membiayainya.

Tanggapan lapangan terhadap kebijakan SBI bervariasi, pada umumnya mereka berpendapat bahwa kebijakan ini bersifat diskriminatif, tetapi di kalangan guru ternyata sebagian besar justru setuju terhadap kebijakan ini dengan alasan untuk peningkatan mutu pendidikan dan untuk daya saing internasional.

\section{Penyelenggaraan Pendidikan yang Bermutu untuk Konteks Indonesia}

Penyelenggaraan pendidikan yang bermutu di Indonesia sebaimana diamanatkan oleh UUD Tahun 1945, UU Nomor 20/2003, Perpres Nomor 7/2005 tentang RPJM, dan PP Nomor 19/2005, yaitu pendidikan yang dapat mengembangkan kemampuan dan watak serta peradaban bangsa, tanggap terhadap perkembangan zaman, mengembangkan potensi peserta didik, mampu menghasilkan manusia yang beriman dan bertakwa kepada Tuhan Yang Maha Esa, berakhlak mulia, sehat, berilmu, cakap, kreatif, mandiri, dan menjadi warga negara yang demokratis serta bertanggung jawab. Dalam PP Nomor 19/2005 dijabarkan bahwa pendidikan yang bermutu harus memenuhi 8 (delapan) standar nasional pendidikan yaitu standar isi, standar proses, standar kompetensi lulusan, standar pendidik dan tenaga kependidikan, standar sarana dan prasarana, standar pengelolaan, standar pembiayaan, dan standar penilaian pendidikan.

Dalam UU Nomor 7/2007 tentang Rencana Pembangunan Jangka Panjang Nasional (RPJPN) Tahun 2005-2025 disebutkan bahwa visi pembangunan nasional Tahun 2005-2025 "Indonesia yang mandiri, maju, adil dan makmur." Untuk mencapai visi tersebut ditempuh melalui 8 (delapan) misi pembangunan nasional, yaitu mewujudkan: 1) masyarakat yang berakhlak mulia, bermoral, beretika, berbudaya dan beradab berdasarkan Pancasila; 2) bangsa yang memiliki daya saing; 3 ) masyarakat yang demokratis berlandaskan hukum; 4) Indonesia yang aman, damai dan bersatu; 5) pemerataan pembangunan dan berkeadilan; 6) Indonesia yang asri dan lestari; dan 7) Indonesia yang mandiri, maju, kuat, berbasiskan kepentingan nasional; serta 8) peran penting Indonesia dalam pergaulan internasional.

UNESCO Tahun 1974 merekomendasikan lima hal tentang pendidikan sebagai salah satu hak dasar manusia, yaitu pendidikan untuk memahami kerjasama internasional, pendidikan untuk perdamaian, pendidikan sebagai hak asasi manusia, serta dasar untuk kebebasan (Jacques Delors, 1996). Pendidikan yang bermutu sebagaimana diusung oleh UNESCO 
harus menekankan pada 4 pilar pendidikan yaitu belajar untuk memahami (learning to know), belajar untuk berbuat (learning to do), belajar untuk menjadi (learning to be), dan belajar untuk hidup bersama (learning to live together).

Pendapat lapangan tentang pengertian penyelenggaraan pendidikan yang bermutu untuk konteks Indonesia dipahami secara bervariasi. Dari kalangan pejabat dan dosen diperoleh pandangan tentang pengertian penyelenggaraan bermutu berbeda-beda, ada yang menekankan pada pengembangan potensi peserta didik, kepuasan pelanggan, pengembangan 3 (tiga) ranah kemampuan (kognitif, afektif, dan psikomotorik), pemberian bekal kemampuan dasar dan moralitas anak, dan ada yang melihatnya dari sisi kualitas keluaran (output) atau lulusan. Sedangkan dari kalangan kepala sekolah, penyelenggaraan pendidikan bermutu berkaitan langsung dengan kualitas guru, kelengkapan sarana-prasarana, dan proses pembelajaran. Dari kalangan guru lebih banyak mengangkat ketersediaan sarana dan prasarna merupakan komponen utama penyelenggaraan pendidikan yang bermutu.

Hampir semua responden dalam penelitian ini berpendapat bahwa kondisi penyelenggaraan pendidikan di Indonesia saat ini belum bermutu. Beberapa penyebabnya rendahnya mutu pendidikan termasuk kurangnya ketersediaan sarana-prasarana, kurangnya kualitas dan kuantitas guru, kebijakan yang sering berubah, kurangnya penekanan proses pembelajaran pada pengembangan potensi diri, kurangnya dana pendukung, sistem penilaian yang mengandalkan ujian akhir sekolah, serta kurangnya kesejahteraan guru.

\section{Alokasi Anggaran Pendidikan di Indonesia Perkembangan Anggaran Pendidikan dalam APBN}

Menurut Amandemen Keempat UUD Tahun 1945 yang terjadi Tahun 2002 dan UU Nomor 20 Tahun 2003 Tentang Sisdiknas, disebutkan bahwa pemerintah wajib membiayai pendidikan dasar dan alokasi anggaran pendidikan minimal $20 \%$ dari APBN dan APBD. Walaupun Amandemen Keempat UUD Tahun 1945 dilakukan pada Tahun 2002, tetapi dalam kenyataannya alokasi anggaran pendidikan belum seperti yang diamanatkan.

Persentase alokasi anggaran pendidikan dalam APBN terjadi peningkatan dari 8,1\% pada Tahun 2005 menjadi $10,1 \%$ (2006), 11,8\% (2007), 15,6\% (2008), dan 20\% (2009 dan 2010). Walaupun terjadi peningkatan, kalau dilihat dari amanat UUD Tahun 1945 angka 20\% barulah mencapai angka batas minimum yang dipersyaratkan, artinya angka tersebut ke depan harus ditingkatkan.

Terkait dengan gaji pendidik, dalam APBN Tahun 2005 dan 2006 tidak ada kejelasan apakah termasuk dalam anggaran pendidikan atau tidak. Pada Tahun 2007 gaji pendidik tidak termasuk dalam anggaran pendidikan, tetapi dalam APBN tiga Tahun

Tabel 2. Perkembangan Anggaran Pendidikan di Indonesia Tahun 2005-2010*) dalam miliar rupiah

\begin{tabular}{|c|c|c|c|c|c|c|}
\hline URAIAN & \multicolumn{6}{|c|}{ APBN *) } \\
\hline & 2005 & 2006 & 2007 & 2008 & 2009 & 2010 \\
\hline $\begin{array}{l}\text { Anggaran Pendidikan } \\
\text { melalui Belanja Pusat }\end{array}$ & 29.308 & 45.304 & 50.843 & 55.298 & 89.550 & 96.480 \\
\hline $\begin{array}{l}\text { Anggaran Pendidikan } \\
\text { melalui Transfer }\end{array}$ & 12.157 & 20.11 & 39.258 & 99.063 & 117.863 & 127.993 \\
\hline $\begin{array}{l}\text { Jumlah Anggaran } \\
\text { Pendidikan }\end{array}$ & 41.465 & 65.414 & 90.101 & 154.361 & 207.413 & 225.229 \\
\hline Total APBN & 511.918 & 647.668 & 763.571 & 989.494 & 1.037 .067 & 1.126 .146 \\
\hline Persentase (\%) & $8,1 \%$ & $10,1 \%$ & $11,8 \%$ & $15,6 \%$ & $20 \%$ & $20 \%$ \\
\hline Gaji Pendidik & - & - & $\begin{array}{l}\text { Tidak } \\
\text { termasuk }\end{array}$ & Termasuk & Termasuk & Termasuk \\
\hline $\begin{array}{l}\text { Anggaran Pendidikan } \\
\text { Kedinasan }\end{array}$ & - & - & $\begin{array}{l}\text { Tidak } \\
\text { termasuk }\end{array}$ & $\begin{array}{l}\text { Tidak } \\
\text { termasuk }\end{array}$ & $\begin{array}{l}\text { Tidak } \\
\text { termasuk }\end{array}$ & $\begin{array}{l}\text { Tidak } \\
\text { termasuk }\end{array}$ \\
\hline
\end{tabular}

*) Diolah dari UU No. 1/2005 tentang APBN Tahun 2005, UU No. 13/25 tentang APBN Tahun 2006, UU No. 18/2006 tentang APBN Tahun 2007, UU No. 16/2008 tentang APBN Tahun 2008, UU No. 41/2008 tentang APBN Tahun 2009, UU No. 2/2010 tentang APBN-PTahun 2010, dan Data Pokok APBN 20052011 dari Kementerian Keuangan Republik Indonesia. 
berikutnya, gaji pendidik dimasukkan sebagai bagian dari alokasi anggaran pendidikan sehingga persentasenya menjadi lebih besar. Dengan memasukkan gaji pendidik ke dalam alokasi anggaran pendidikan, peningkatan persentase tersebut tidak selalu berarti peningkatan anggaran pendidikan. Sedangkan untuk biaya pendidikan kedinasan tidak diperhitungkan sebagai bagian dari anggaran pendidikan dalam APBN sejak Tahun 2007 sampai Tahun 2010.

Anggaran pendidikan dalam APBN ternyata tidak hanya dikelola oleh Kementerian Pendidikan Nasional dan Kementerian Agama, tetapi sebesar 5\% Tahun 2009 dan 7\% Tahun 2010 dikelola oleh 15 kementerian/lembaga lain yaitu Departemen Pekerjaan Umum, Departemen Kebudayaan dan Pariwisata, Perpusnas, Departemen Keuangan, Departemen Pertanian, Departemen Perindustrian, Departemen Energi dan Sumber Daya Mineral, Departemen Perhubungan, Departemen Kesehatan, Departemen Kehutanan, Departemen Kelautan dan Perikanan, Badan Pertanahan Nasional, Badan Meteorologi dan Geofisika, Badan Tenaga Nuklir Nasional, serta Bagian Anggaran 69. Hal ini menjadi pertanyaan, apakah anggaran tersebut benar-benar untuk mendukung pendidikan padahal kementerian/ lembaga tersebut tidak menangani pendidikan.

\section{Perkiraan Kebutuhan Anggaran untuk Mendukung Penyelenggaraan Pendidikan yang Bermutu Jenjang Sekolah Dasar Satuan Biaya Pendidikan Jenjang Sekolah Dasar}

Survei yang bertujuan untuk melakukan analisis kebutuhan sekolah dalam rangka melakukan penghitungan satuan biaya pendidikan pada jenjang sekolah dasar telah dilakukan di tujuh dari delapan
Sekolah Dasar Percontohan Provinsi DKI Jakarta. Dari hasil survei diperoleh informasi bahwa satuan biaya pendidikan untuk sekolah dasar adalah sebesar Rp 1.767.000,00 per siswa per Tahun yang terdiri atas biaya investasi Rp508.000,00 dan biaya operasi nonpersonalia Rp1.259.000,00. Sementara itu beban orangtua untuk mengirimkan anaknya ke sekolah adalah Rp8.867.000,- per siswa per Tahun.

\section{Perkiraan Kebutuhan Anggaran untuk Mendukung Penyelenggaraan Pendidikan Bermutu Jenjang Sekolah Dasar Secara Nasional}

Alokasi biaya pendidikan yang diperlukan untuk mendukung menyelenggarakan pendidikan yang bermutu jenjang sekolah dasar secara nasional bagi 26.984.824 anak adalah sebesar $\mathrm{Rp}$ 45.750.950.103.000,00,00 atau sekitar Rp46 trilyun. Selain itu masih harus ditambah dengan kewajiban pemerintah untuk membantu anak usia sekolah dasar dari keluarga kurang mampu sebesar Rp33 trilyun untuk menjamin mereka dapat mengikuti pendidikan. Dengan demikian perkiraan kebutuhan anggaran pendidikan untuk mendukung penyelenggaraan pendidikan yang bermutu jenjang sekolah dasar secara nasional adalah sebesar Rp79 trilyun.

\section{Simpulan dan Saran Simpulan}

Pertama, konsistensi kebijakan pembiayaan pendidikan di Indonesia menunjukkan bahwa: a) Terdapat perbedaan substansi antara UUD Tahun 1945 dan UU Nomor 20 Tahun 2003 tentang Sistem Pendidikan Nasional yaitu menyangkut frasa "gaji pendidik dan biaya pendidikan kedinasan" dalam alokasi anggaran pendidikan; b) Terdapat ketidak-

Tabel 3. Satuan Biaya Pendidikan Jenjang Sekolah Dasar Per Siswa Tahun 2010

\begin{tabular}{|c|c|c|c|}
\hline No & Jenis Biaya & $\begin{array}{c}\text { Satuan Biaya Per Siswa } \\
\text { Per Tahun (Rp) }\end{array}$ & $\begin{array}{l}\text { Beban Orangtua Per } \\
\text { Siswa Per Tahun (Rp) }\end{array}$ \\
\hline 1 & Biaya Investasi *) & $508.000,-$ & - \\
\hline 2 & Biaya Operasi Personalia & & - \\
\hline 3 & Biaya Operasi Nonpersonalia & $1.259 .000,-$ & - \\
\hline 4 & Biaya Pribadi Siswa & & $8.867 .000,-$ \\
\hline & Jumlah & $1.767 .000,-$ & $8.867 .000,-$ \\
\hline
\end{tabular}

*) Biaya investasi dalam tabel tidak termasuk sarana meubelair, prasarana (lahan, ruang kelas, ruang pimpinan satuan pendidikan, ruang pendidik, ruang tata usaha, ruang perpustakaan, ruang laboratorium, ruang bengkel kerja, ruang unit produksi, ruang kantin, instalasi daya dan jasa, tempat berolahraga, tempat beribadah, tempat bermain, tempat berkreasi), dan biaya modal tetap. 
sesuaian antarpasal dalam UU Sisdiknas pada bagian yang mengatur kewajiban pemerintah untuk membiayai pendidikan dasar dan kewajiban masyarakat untuk mendukung sumber daya untuk penyelenggaraan pendidikan; c) Terdapat ketidaksesuaian antara PP Nomor 19/2005, PP Nomor 47/ 2008, dan PP Nomor 48/2008, yaitu mencakup ketidakkonsistenan dalam pengunaan istilah, cakupan substansi, ketidaktegasan dan ketidakjelasan maksud, serta perbedaan dalam cara pengelompokan komponen pembiayaan. Selain itu PP Nomor 48/ 2008 membolehkan adanya pungutan, tetapi PP Nomor 47/2008, UU Sisdiknas, dan bahkan UUD Tahun 1945 melarangnya; c) Pada tataran implementasi, kebijakan pemberian Bantuan Operasional Sekolah (BOS) untuk Pendidikan Gratis dalam rangka Wajib Belajar 9 Tahun Yang Bermutu, dilihat dari Pasal 31 Ayat (2) UUD Tahun 1945, kebijakan tersebut merupakan bentuk pengingkaran pemerintah terhadap kewajibannya untuk membiayai pendidikan dasar (bukan sekedar memberikan bantuan); e) Besaran alokasi BOS untuk pendidikan gratis dalam rangka wajib belajar pendidikan dasar yang bermutu, tidak sesuai dengan standar biaya operasi yang dikeluarkan Pemerintah dan masih jauh dari kebutuhan; dan f) Kebijakan penyelenggaraan sekolah bertaraf internasional yang diatur dalam UU Nomor 20/2003, PP Nomor 17/2010, PP Nomor $66 / 2010$ dan Peraturan Mendiknas Nomor 78/2009, merupakan kebijakan diskriminatif dan bertentangan dengan UUD Tahun 1945. Tetapi menurut kepala sekolah dan guru, sebanyak $66 \%$ responden berpendapat bahwa kebijakan ini tidak diskriminatif dengan alasan utama karena tuntutan mutu pendidikan dan kesejajaran dengan negara lain.

Kedua, penyelenggaraan Pendidikan Yang Bermutu untuk Konteks Indonesia menunjukkan bahwa: a) Penyelenggaraan pendidikan yang bermutu menurut UUD Tahun 1945 dan UU Sisdiknas adalah pendidikan yang diselenggarakan secara sadar dan terencana untuk mewujudkan suasana belajar dan proses pembelajaran sedemikian hingga peserta didik dapat secara aktif mengembangkan semua potensi dirinya dalam rangka memiliki kemampuan spiritual, mengendalikan diri, kepribadian, kecerdasan, akhlak mulia, serta keterampilan yang diperlukan bagi dirinya sebagai individu, bagi masyarakat, bangsa dan negara; b) Penyelenggaraan pendidikan yang bermutu dijabarkan dalam PP Nomor 19 Tahun 2005 adalah pendidikan yang memenuhi delapan standar nasional pendidikan yaitu standar isi, standar proses, standar kompetensi lulusan, standar pendidik dan tenaga kependidikan, standar sarana dan prasarana, standar pengelolaan, standar pembiayaan, dan standar penilaian pendidikan; dan c) Penyelenggaraan pendidikan yang bermutu berdasarkan rekomendasi dari UNESCO harus mencakup 4 pilar yaitu learning to know, learning to do, learning to be, dan learning to live together.

Ketiga, alokasi anggaran pendidikan di Indonesia menunjukkan bahwa: a) Anggaran pendidikan menurut UUD Tahun 1945 yang diamandemen Tahun 2002 dan ditegaskan dalam UU Nomor 20 Tahun 2003 tentang Sisdiknas, harus dialokasikan minimal $20 \%$ dari APBN dan APBD. Tetapi berdasarkan data yang ada alokasi anggaran pendidikan baru mencapai 20\% dari APBN pada Tahun 2009, artinya pencapaian angka minimum terjadi tujuh Tahun setelah pencantuman angka tersebut dalam Amandemen Keempat UUD Tahun 1945; b) Dari sisi perkembangan persentase alokasi anggaran pendidikan dari Tahun ke Tahun mengalami kenaikan yang signifikan, tetapi kenaikan dari 11,8\% pada Tahun 2007 tidak termasuk gaji pendidik menjadi $20 \%$ pada Tahun 2009 termasuk gaji pendidik; c) Anggaran pendidikan pada Tahun 2009 dan 2010 yang dialokasikan melalui belanja Pemerintah pusat dikelola oleh Departemen Pendidikan Nasional, Departemen Agama, dan 15 kementerian/lembaga lain; dan d) Alokasi anggaran pendidikan Tahun 2010 di Kementerian Pendidikan Nasional adalah untuk mendukung wajib belajar pendidikan dasar (44\%), pendidikan tinggi (36\%), pendidikan menengah $(9 \%)$, mutu pendidik dan tenaga kependidikan (4\%), dan lain-lain (7\%).

Keempat, perkiraan kebutuhan anggaran pendidikan jenjang sekolah dasar menunjukkan bahwa: a) Satuan biaya pendidikan pada jenjang sekolah dasar dalam rangka penyelenggaraan pendidikan yang bermutu adalah sebesar Rp1.767.000,00 per siswa per Tahun. Sedangkan beban orangtua untuk mengirimkan anaknya ke sekolah dasar adalah Rp 8.867.000,00 per siswa per Tahun; dan b) perkiraan kebutuhan anggaran untuk mendukung penyelenggaraan sekolah dasar yang bermutu secara nasional pada Tahun 2010 adalah Rp79 trilyun yang terdiri atas biaya operasional sekolah Rp46 trilyun dan bantuan kepada anak usia sekolah dasar yang berasal dari keluarga ekonomi 
kurang mampu sebesar Rp33 trilyun.

\section{Saran}

Mengacu pada hasil simpulan di atas, maka disarankan hal-hal sebagai berikut:

Pertama, bagi pembuat kebijakan: a) Peraturan perundangan yang menyangkut pembiayaan pendidikan mulai dari UU Nomor 20/2003, PP Nomor 19/2005, PP Nomor 47/2008, dan PP Nomor 48 pada bagian atau pasal yang mengatur tentang pembiayaan pendidikan perlu ditinjau kembali pada untuk menghindari ketidaksinkronan baik antarpasal dalam UU dan PP maupun terhadap UUD Tahun 1945; b) Kebijakan pemberian bantuan operasional sekolah untuk pendidikan gratis dalam rangka wajib belajar pendidikan dasar perlu diluruskan dari sekedar bantuan menjadi biaya operasional sekolah karena pemerintah wajib membiayai penyelenggaraan pendidikan dasar; c) Kebijakan penyelenggaraan sekolah bertaraf internasional perlu ditinjau kembali karena bertentangan dengan UUD Tahun 1945 dan UU Sisdiknas karena kebijakan tersebut bersifat diskriminatif dan harus diselenggarakan tanpa memungut biaya. Konsekuensinya, Peraturan Mendiknas Nomor 78 Tahun 2009 tentang Penyenggaraan Sekolah Bertaraf Internasional pada Jenjang Pendidikan Dasar dan Menengah harus ditinjau kembali bahkan dibatalkan; d) Untuk mendukung penyelenggaraan pendidikan, pemerintah harus meningkatkan alokasi anggaran pendidikan pada jenjang sekolah dasar Tahun 2010 dari Rp 11 trilyun menjadi Rp 46 trilyun untuk menjamin bahwa penyelenggaraan pendidikan gratis jenjang sekolah dasar, ditambah Rp33 trilyun untuk menjamin agar setiap warga negara dari keluarga kurang mampu dari segi ekonomi dapat mengakses pendidikan yang bermutu; e) Pemerintah harus melaksanakan amanat UUD Tahun 1945 dan UU Sisdiknas dengan memprioritaskan anggaran pendidikan minimum $20 \%$ dari APBN dan APBD untuk menyelenggarakan pendidikan yang bermutu tanpa kompromi; dan f) Pemerintah perlu memberikan penjelasan tentang penggunaan anggaran pendidikan yang dikelola oleh kementerian dan lembaga nonpendidikan.

Kedua, bagi peneliti: a) Penelitian ini hanya fokus pada pembiayaan pendidikan, dengan demikian terbuka kesempatan untuk melakukan analisis kebijakan dengan fokus lain misalnya penelitian dari sisi pemerataan dan keadilan dalam pelayanan pendidikan bagi setiap warga negara; $b$ ) Penghitungan satuan biaya pendidikan dalam penelitian ini hanya difokuskan pada jenjang sekolah dasar, sehingga dapat dilakukan penelitian lebih lanjut untuk menghidung satuan biaya pendidikan dasar pada jenjang yang lain; c) Penelitian ini dilakukan dengan mengambil sampel sekolah dasar percontohan di wilayah DKI Jakarta, sehingga terbuka kesempatan untuk melakukan penelitian serupa dengan sasaran sampel penelitian sekolah dasar yang representatif untuk seluruh kawasan Indonesia; dan d) Perlu diteliti lebih lanjut tentang hubungan antara ketersediaan sarana-prasarana pendidikan dan kualitas pendidikan. Selain itu perlu digali kemungkinan faktor selain sarana-prasarana yang dapat mempengaruhi mutu pendidikan.

Ketiga, bagi kepala sekolah dan guru: a) Upaya untuk meningkatkan mutu pendidikan di tingkat sekolah, dapat dilakukan antara lain melalui peningkatan profesionalisme guru secara terusmenerus baik dalam rangka peningkatan kemampuan dan keterampilan, penambahan wawasan maupun memperbarui (update) pengetahuan; b) Pemenuhan sarana dan prasarana pendidikan di tingkat sekolah perlu mendapatkan prioritas untuk mendukung dan memenuhi kebutuhan guru dalam menyelenggarakan kegiatan belajarmengajar yang berkualitas; dan c) Selama kebijakan sekolah bertaraf internasional belum direvisi, perlu diterapkan sistem subsidi silang untuk memberi kesempatan kepada anak dari keluarga kurang mampu secara ekonomi untuk mengikuti pendidikan yang bermutu untuk mengurangi kesan diskriminatif.

\section{Pustaka Acuan}

Abas Ghozali, Siswantari, Herlinawati, Prayitno, Simon Sili Sabon, Fajarini, Indriyati, Dwi Winanto, dan Ani Sri Surwayani. 2004. Analisis Biaya Pendidikan Dasar dan Menengah. Jakarta: Balitbang-Depdiknas Ann Majchrzak,1984. Methods for Policy Research. Sydney: SAGE Publication, Inc.

Djaali. 2006. Psikologi Pendidikan. Jakarta: Bumi Aksara 
Douglas Ray, Birgit Brock Utne, Beatriz Franco, Ratna Ghosh, Magnus Haavelsrud, Assa Ibrahim, Malavika Karlekar, Norrel London, Ruth Malisa, Maria Amelia Palacios Vallejo, Vlastimil Parizek, David Radcliffe, Dien Iran, Natalis Voskresenskaya, and Jhon Nan-Jhas. 1994. Education for Human Rights. An International Perpective. Paris: UNESCO

Edi Suharto. 2005. Analisis Kebijakan Publik. Bandung: Alfabeta

Federico Mayor. 2001. What Future for Human Rights dalam Keys to the 21st Century. Paris: UNESCO Publishing/Berghahn Books

Frank W. Banghart \& Albert Trull, JR. 1973. Educational Planning. London: The Macmillan Company

Frederick Harbison and Charles A. Myers, 1965. Manpower and Education: Country Studies in Economic Development. New York: McGraw-Hill Book Company

Jacques Delors, In'am Al Mufti, Isao Amagi, Roberto Carnieo, Fay Chung, Bronislaw Geremek, William Gorham, Aleksandra Kornhauser, Michael Manley, Marisela Padron Quero, Marie-Angelique Savane, Karan Singh, Rodolfo Stavenhagen, Myong Won Suhr, Zhou Nanzhao. 1996. Learning: The Treasure Within. Report to UNESCO of the International Commission on Education for the Twenty-first Century. Paris: UNESCO Publishing

Kementerian Keuangan Republik Indonesia. Nota Keuangan RAPBN 2011, RUU APBN 2011 \& Data Pokok APBN Tahun 2005-2011. Online di http://www.anggaran.depkeu.go.id/web-contentlist.asp?ContentId $=806$

Keputusan Kepala Dinas Pendidikan Dasar Provinsi DKI Jakarta Nomor 35/2006 tanggal 20 Februari 2006 tentang Pedoman Penyusunan Rencana Anggaran Pendapatan dan Belanja Sekolah untuk Sekolah Dasar Negeri, Sekolah Menengah Pertama Negeri, dan Sekolah Luar Biasa Negeri Provinsi DKI Jakarta

Ketetapan MPR Republik Indonesia Nomor III/MPR/2000 tentang Sumber Hukum dan Tata Urutan Peraturan Perundang-undangan

Komisi Nasional Pendidikan. 2001. Menuju Pendidikan Dasar Bermutu dan Merata. Jakarta: Depdikbud

Les Bell and Howard Stevenson, 2006. Education Policy: Process, Themes and Impact, New York: Routledge

Majelis Permusyawaratan Rakyat. Perubahan Keempat Undang-Undang Dasar Negara Kesatuan Republik Indonesia Tahun 1945

Mark Bray, 1996. Decentralization of Education. Community Finance. Washington: The World Bank

Martin Carnoy \& Henry M. Levin, 1976. The Limit of Educational Reform. New York: David McKay Company, Inc.

McMahon, Nanik Suwaryani, Boediono, dan Elizabeth Appiah. 2001. Improving Education Finance in Indonesia. Jakarta: Depdiknas-UNESCO-UNICEF

Peraturan Menteri Pendidikan Nasional Nomor 15 Tahun 2010 tentang Standar Pelayanan Minimal Pendidikan di Kabupaten/Kota.

Peraturan Menteri Pendidikan Nasional Nomor 2 Tahun 2008 tentang Buku

Peraturan Menteri Pendidikan Nasional Nomor 63 Tahun 2009 tentang Sistem Penjaminan Mutu Pendidikan

Peraturan Menteri Pendidikan Nasional Nomor 69 Tahun 2009 tentang Standar Biaya Operasi Nonpersonalia Tahun 2009 untuk SD/MI, SMP/MTs, SMA/MA, SMK, SDLB, SMPLB, dan SMALB

Peraturan Menteri Pendidikan Nasional Nomor 78 Tahun 2009 tentang Penyelenggaraan Sekolah Bertaraf Internasional (SBI) Pada Jenjang Pendidikan Dasar dan Menengah.

Peraturan Pemerintah Nomor 17 Tahun 2010 tentang Pengelolaan dan Penyelenggaraan Pendidikan

Peraturan Pemerintah Nomor 19 Tahun 2005 tentang Standar Nasional Pendidikan

Peraturan Pemerintah Nomor 47 Tahun 2008 tentang Wajib Belajar

Peraturan Pemerintah Nomor 48 Tahun 2008 tentang Pendanaan Pendidikan

Peraturan Pemerintah Nomor 66 Tahun 2010 tentang Perubahan Peraturan Pemerintah Nomor 17 Tahun 2010 
Peter Capezio. 2000. Powerful Planning Skills (Alih bahasa oleh Soesanto). Jakarta: Elex Media Komputindo.

Riant Nugroho D. 2007. Analisis Kebijakan. Jakarta: PT Gramedia

Risalah Sidang Mahkamah Konstitusi Republik Indonesia Nomor 24/PUU-V/2007 perihal Pengujian Undangundang Republik Indonesia Nomor 20 Tahun 2003 tentang Sistem Pendidikan Nasional Khusus Pasal 49 Ayat (1) dan Undang-undang Nomor 18 Tahun 2006 tentang APBN Tahun Anggaran 2007 terhadap Undang-Undang Dasar 1945

Roe L. Johns \& Edgar L. Morphet. 1969. The Economics and Financing of Education. A System Approach ( $2^{\text {nd }}$ Edition). London: Printice-Hall International

Shenith Jackson. 2008. Definition of Education. Online at www.helium.com

Soedijarto. 2008. Landasan dan Arah Pendidikan Nasional Kita. Jakarta: Kompas

Supriadi, Dedi. 2003. Satuan Biaya Pendidikan Dasar dan Menengah. Bandung: PT Remaja Rosdakarya

Suyanto \& Djihad Hisyam. 2000. Refleksi dan Reformasi. Pendidikan di Indonesia Memasuki Milenium III. Yogyakarta: Adicita Karya Nusa

The World Bank. 2005. Human Development Sector Reports. Education in Indonesia: Managing the Transition to Decentralization. Jakarta: The World Bank, AusAID, Depdiknas

Thomas J. Barry. 1996. Excellent is A Habit. How to Avoid Quality Burnout. Kualalumpur: Golden Books Centre, Sdn. Bhd.

Undang-Undang Dasar Negara Kesatuan Republik Indonesia Tahun 1945

Undang-Undang Nomor 1 Tahun 2005 tentang Anggaran Pendapatan dan Belanja Negara (APBN) Tahun 2005

Undang-Undang Nomor 13 Tahun 2005 tentang Anggaran Pendapatan dan Belanja Negara (APBN) Tahun 2006

Undang-Undang Nomor 14 Tahun 2005 tentang Guru dan Dosen

Undang-Undang Nomor 16 Tahun 2008 tentang Anggaran Pendapatan dan Belanja Negara (APBN) Tahun 2008

Undang-Undang Nomor 18 Tahun 2006 tentang Anggaran Pendapatan dan Belanja Negara (APBN) Tahun 2007

Undang-Undang Nomor 2 Tahun 2010 tentang Anggaran Pendapatan dan Belanja Negara Perubahan Tahun 2010

Undang-Undang Nomor 20 Tahun 2003 tentang Sistem Pendidikan Nasional;

Undang-Undang Nomor 32 Tahun 2004 tentang Pemerintahan Daerah

Undang-Undang Nomor 33 Tahun 2004 tentang Perimbangan Keuangan antara Pemerintah Pusat dan Daerah

Undang-Undang Nomor 41 Tahun 2008 tentang Anggaran Pendapatan dan Belanja Negara (APBN) Tahun 2009

Undang-Undang Nomor 7 Tahun 2007 tentang Rencana Pembangunan Jangka Panjang Nasional Tahun 2005-2025

UNDP, BPS, Bappenas. 2004. National Human Development Report 2004. The Economics of Democracy. Financing Human Development in Indonesia. Jakarta: BPS-Statistics Indonesia, Bappenas, BPS,

Wyne Parsons. 2001. Public Policy. An Introduction to the Theory and Practice of Policy Analysis, Edward Elgar Publishing, Ltd. 2001, dialihbahasakan oleh Tri Wibowo Budi Santoso, 2005. Jakarta: Prenada Media 